\title{
African Diasporas: Toward a Global History
}

\author{
Paul Tiyambe Zeleza
}

Editors' note: The following article is a slightly revised version of the Presidential Address delivered at the fifty-second Annual Meeting of the African Studies Association in New Orleans in 2009.

Abstract: This article interrogates the development of African diaspora studies. Based a global research project that seeks to map out the dispersals of African peoples in all the major regions of the world, compare the processes of diasporization, and examine the patterns of diaspora engagements, it offers a vigorous critique of the hegemonous Afro-Atlantic model in African diaspora studies. It focuses on two critical challenges that students of African diasporas must confront: the terms of analysis that are adopted, and the problems of historical mapping.

Over the past five years, I have traveled to different parts of the world in search of African diasporas for a project entitled "Africa and Its Diasporas: Dispersals and Linkages," which was generously funded by the Ford Foundation. The project took me to sixteen countries: four in continental South and North America (Brazil, Venezuela, Mexico, and Canada); four in the Caribbean (Trinidad, Haiti, Cuba, and the Bahamas); four in Europe (Germany, Britain, France, and Spain); and four in Asia (India, Qatar, Dubai, and Oman). This is what I would like to share with you in this presentation: my search for peoples of African descent and their histories, trying to decipher the threads that tie them together and distinguish them from one another.

African Studies Review, Volume 53, Number 1 (April 2010), pp. 1-19

Paul Tiyambe Zeleza is the dean of the Bellarmine College of Liberal Arts and Presidential Professor of African American Studies and History at Loyola Marymount University. He served as the director of the Center for African Studies at the University of Illinois at Urbana-Champaign, and was the Liberal Arts and Sciences Distinguished Professor and head of the Department of African American Studies at the University of Illinois at Chicago. He is the author of two dozen books, several of which have won international awards, and numerous articles. E-mail: paul.zeleza@lmu.edu 
As with most of our intellectual projects, this research venture was inspired by my personal and professional biographies, my paradigmatic and political quests, my family's migratory and diasporic histories, my disciplinary and interdisciplinary proclivities, and my pan-African and internationalist passions. The spark came in 2002 when I met my dear friend Tade Aina in Nairobi. He was then working for the Ford Foundation, which had sponsored a visit to East Africa of Afro-Indians, the Sidis, and we discussed how wonderful it would be to do a project comparing the African diasporas of the Atlantic and Indian Ocean worlds. I was intrigued. Three years later, I was ready to embark on the project.

I sought to do three things: to map out the dispersals of African peoples in Asia, Europe, and the Americas; compare the processes of diaspora formation within and among these regions; and examine the ebbs and flows of linkages and exchanges-demographic, cultural, economic, political, ideological, and iconographic-between these diasporas and Africa. Following the global departures, dispersals, and destinations of African peoples has meant tracing their material and discursive journeys; that is, simultaneously unraveling the complex and messy historical processes behind their movements and formations, unpacking the analytical frameworks that inform our analyses, and identifying the political interests that undergird our research projects on this subject.

As a student of the history of ideas and knowledge production, I was only too aware that the field of African diaspora studies is not only framed by our respective disciplinary and interdisciplinary locations as researchers, not to mention our indelible social inscriptions, but like all fields of intellectual inquiry, it is also mediated and marked by the unyielding demands of historical geography and the hegemonies and hierarchies in the international division of intellectual production. This is one reason I sought to visit the different countries and regions that constitute the African diaspora world-to learn of the regional, national, and local histories and discourses. It is indeed a world of bewildering diversity, but there are complex threads of connections, convergences, and commonalities.

Our challenge, it seems to me, is to resist both the tyranny of hegemonic models and the romance of the local, and to develop analytical models that are historically grounded and theoretically suggestive-that are sensitive to local experiences without losing sight of the global forces that structure them, and of the multilayered intersections between African history and world history. I could say much about my encounters, experiences, conversations, observations, and confusions during my visits to the sixteen countries, but there is obviously no time for that. In this presentation, I want to share with you only two of the many challenges I have had to confront in thinking about African diasporas from a global perspective. The first concerns the terms of analysis we adopt, the second the problems of historical mapping. 


\section{Conceptual Challenges}

The growth of African diaspora studies as a field of scholarly inquiry over the last three decades has been nothing short of phenomenal. It is tied in complex ways to several developments within and outside the academy. The intellectual dynamics include the growth of African studies itself, of ethnic and minority studies, and of the Africana studies movement. It can also be attributed to the rise of cultural studies, postcolonial studies, and globalization studies, which collectively recast the questions of culture, identity, and transnationalism in African studies that previously were dominated by structuralist perspectives inspired by Marxist and dependency paradigms superimposed on age-old Eurocentric notions of eternal African marginality-the strange fiction that the continent was irredeemably irrelevant and splendidly isolated from the rest of the world. ${ }^{1}$

Part of the appeal of the diaspora paradigm is that it reconnects Africa to its peoples dispersed around the world and globalizes Africa, repositioning the continent in world history. The Afro-Asian connection disrupts Eurocentric narratives of global history by demonstrating independent transoceanic and transcontinental interactions between Africa and Asia. Those who believe in the Afro-Asian dialogue of Bandung even hope that the intermingled histories of African diasporas in Asia and Asian diasporas in Africa can help rescue the thickening circuits of Afro-Asian engagements from crass commercialization and rekindle the more progressive solidarities of the heyday of decolonization and Third World militancy. ${ }^{2}$

Accompanying these intellectual imperatives are institutional dynamics-the establishment of centers, institutes, or programs of Africana and diaspora studies, and the emergence of journals, book series, and research funding on the subject. As with any field of scholarship, once you build the institutional architecture, research and publications tend to follow, discourses and debates are manufactured, careers are made and unmade. Over the last five years I have watched the literature on African diasporas explode as scores of books and hundreds of articles are published each year. Trying to keep up with the literature has become increasingly impossible for any one individual.

The intellectual and institutional dynamics promoting diaspora studies have been facilitated and reinforced by ideological imperatives, the investment by states and various publics in diaspora communities, and the popular discourses by and on diaspora populations, perspectives, problems, and possibilities. The discovery by African states and development agencies of the new African diasporas as a developmental asset, as the continent's major donor-responsible for between $\$ 50$ and $\$ 150$ billion in remittance flows according to various estimates-is complimented by a growing consciousness on the part of the diasporas themselves and their capacity to act as powerful transnational forces. ${ }^{3}$ 
This is best encapsulated in the designation of the diaspora by the African Union as Africa's sixth region, although the implications of this are yet to be fully spelled out. In the meantime, many diaspora communities themselves have become more vocal in their self-representation, in their demands for difference and inclusion. This reflects, on the one hand, the globalization of panethnic identities and racial formations, both old and new, and on the other hand, the growth of bureaucratic multiculturalism. The role of international forums cannot be discounted. In this context one can mention the mobilizational effects on African diasporas from Brazil to India of the 2001 U.N. World Conference against Racism.

It has become increasingly clear to me that as the field grows, the need to clarify the terms of discourse and analysis is more imperative than ever. The first issue concerns hegemonies in African diaspora studies: the where, when, what, why, and who is privileged in the field. The second involves the need to clarify the key concepts we use in structuring our methodological and theoretical frameworks. Conceptual clarification entails specifying our intellectual and ideological interests, identifying disciplinary and interdisciplinary influences, and problematizing our analytical metaphors and interpretive analogies.

Among scholars of African diasporas in Asia and Europe, common critiques are heard against the domination of the Afro-Atlantic model and the African Americanization of Afro-Europe and Afro-Asia. There is no question that the Atlantic model dominates African diaspora studies, which focus on movements from western Africa to the Americas through the forced migrations of the Atlantic slave trade and are preoccupied with the construction of "black" identities. But African American hegemony in diaspora studies both in the Americas and in its export to other world regions is not simply a question of what could be called, to paraphrase Gordon Lewis's (1999) term, epistemological bad faith. The hegemony or universalizing ambitions of the Atlantic model are based partly on the sheer size of the Afro-Atlantic diasporas in the Americas, which currently number more than 160 million people (more than 100 million in South America, 40 million in North American, and 22 million in the Caribbean).

They are also embedded in the very cultural and economic hegemony of the United States. This has become a heated issue at international diaspora conferences, as Darlene Clark Hine et al. (2009) and Carole Boyce Davies (2008) note in their recent publications, Black Europe and the African Diaspora and the three-volume Encyclopedia of the African Diaspora, respectively. This was also evident at the First International Conference on the African Diaspora in Asia held in Goa, India, in January 2006 (Prasad \& Angenot 2008).

During my travels, I often had to fend off suspicions that I had come to propagate exclusively American conceptions of African diasporas, and I agree with both Hine et al. and Davies that such critiques and suspicions cannot be wished away. We need to confront the asymmetries in knowledge 
production about African diasporas in different world regions, desist from imposing models derived from specific African American experiences, and understand how much there is to gain from truly comparative perspectives and historiographies.

This is the source of my argument that we need to de-Atlanticize and de-Americanize the histories of African diasporas. In order for the field to grow, it is critical that the Afro-Atlantic and U.S. African American models of African diaspora studies be provincialized rather than universalized, as is the tendency among many of us in the U.S. and Anglophone academies for whom the world beyond our borders can only be simulated copies of our own and for those elsewhere who are anxious to signal their cosmopolitan familiarity with the intellectual products of the world's largest academic system by producing mimic histories.

Let me comment on two epistemic challenges we face, rooted in the very term "African diaspora." Let's begin with the second word. How do we define diaspora in terms of process, spatiality, and periodization? Diasporas emerge out of processes involving movement, migration from a "here" to a "there," from a homeland, real or imagined, to a hostland, loved or hated. But the relationship between dispersal and diasporization is complicated, for dispersed people can "return" or "disappear" through assimilation. In short, diasporas are born, breed, and can die, and they even can undergo reincarnation or resurrection in future generations. Movements can be short, circulatory and permanent, generational and transgenerational in their longevity. Surely not every movement out of one's community, country, or continent qualifies to be called diasporic.

Equally vexing is the question of the spatial scale of diaspora formations, the boundaries that define the process of diasporization-should they be deemed primarily in trans-ethnic, trans-national, or trans-continental terms? Today one can of course talk simultaneously of someone from East Africa as a member of the Luo, Kenyan, East African, and African diasporas in the United States, as many people refer to President Obama. One can also talk of the Luo, Kenyan, and East African diasporas in South Africa, but it would be an oxymoron to refer to these people as an African diaspora insofar as both Kenya and South Africa are African countries.

Since all four spatio-social referents-ethnic, national, regional, and continental-as embodiments of social identities are historical constructs, it raises the question of periodization: how far back we can push certain diaspora identities. The fact that African states are recent colonial inventions that did not exist 150 years ago except for the notable exceptions of Egypt, Morocco, and Ethiopia might explain why the Afro-Atlantic diasporas that emerged out of earlier movements and which did not by and large come from these countries are simply called "African" or identified by their ethnic or regional names. Good examples include Toyin Falola and Matt Childs's The Yoruba Diaspora in the Atlantic World (2004) and Linda M. Heywood and John Thornton's Central Africans, Atlantic Creoles, and the 
Foundation of America (2007). Notions of "Asian" or "European" diasporas are not as widespread, since they are often trumped by national identitiesthe Irish diaspora, the Italian diaspora, the Indian diaspora, the Chinese diaspora, and so on. For Africa, this is of course becoming increasingly true for the "new" diasporas, whose national identities compete with or subsume their continental identities. ${ }^{4}$

The other conceptual challenge concerns the meaning of the first part of the pairing in the term "African diaspora." What is "Africa" and who are "Africans" that constitute, when dispersed and reconstituted, "African diasporas"? As we all know, the idea of "Africa" is an exceedingly complicated one with multiple genealogies and meanings. African identities, peoples, and cultures are often mapped, and differentiated, in racial, geographical, historical, or ideological terms. Ironically, all of the seven sources of the term "Africa" originally referred to locations in the northern part of the continent, but now the term has become almost synonymous with subSaharan Africa. ${ }^{5}$

It can be argued that "Africa" is a material and imagined place, a historical geography, the constellation of the places and peoples embedded in its conceptual bosom. It is just as much an invention as is the notion of "Asia" or "Europe" - which geographically are of course one continentor the even more facetious constructs of the "West" and the "East"-and all such civilizational spaces. But it has a physical, political, psychic, and paradigmatic reality for the peoples who live within or are molded from its cartographic and cultural boundaries, who themselves are subject to spatial shifts and historical transformations. "Africa," I would submit, is more "African" today than it has ever been because it is increasingly a construct produced and consumed across the continent itself, from sports to television to politics, from the All-Africa Games to Big Brother Africa to the African Union.

This implies that our conception of "African diasporas" crucially depends on how we define these very terms, and these definitions in turn have national and transnational contexts that frame them. This is merely to stress the obvious point that hegemonic ideas ride on the hegemonies of material power. This is why the Afro-Atlantic and the African American models are dominant, but it is for the same reason that they should not be applied to other world regions unquestioningly, however accurately they capture and explain the historical experiences and struggles in the Afro-Atlantic world and the United States. Even internally, as we all know, these models are not cast in the iron grid of methodological and theoretical rigidity. But as is often the case with discursive exports, they acquire the conceits of suffocating homogeneity as they cross the Atlantic to foreign lands.

The Atlantic model is problematic when applied to other world regions and periods in part because it is premised on a conception of "Africa" as "sub-Saharan Africa," a racialized construct that haunted African studies 
in Euroamerica over the last century and that some African scholars have desperately sought to deconstruct. This reflects the dominance in the EuroAmerican academy of the Atlantic model and of race in the fields of African studies in general and African diaspora studies in particular. Quite predictably, "black" is the paradigmatic trope in Afro-Atlantic diaspora studies, the pivot around which discourses of "African" diaspora identities, subjectivities, transnationalisms, engagements, or dialogues are framed and debated.

This is quite evident in several recent studies. Let me just mention three, all published in 2009. The first is Patrick Manning's The African Diaspora: A History Through Culture, which despite its global ambitions remains trapped in Eurocentric cartographic conceptions of Africa as sub-Saharan Africa and American preoccupations with the black diaspora. The others openly substitute "Africa" with "black." The two-volume Encyclopedia of Blacks in European History and Culture (Martone 2009) focuses on the historical experiences in Europe of peoples from sub-Saharan Africa except where an Afrocentric claim cannot be resisted and North Africa is sneaked in. In Black Europe and the African Diaspora by Hine at al., the mostly U.S.-based authors have great difficulty in explaining what they mean by "Black Europe," and their African diaspora in Europe excludes North Africans, who surely do have a claim to an African origin and identity as much as the descendants of diasporans from the Americas who have relocated to Europe or the offspring of migrants from sub-Saharan Africa. Indeed, there has been a proliferation of studies on "Black Europe" that are largely patterned on "Black America" and remain trapped in the racialized discourses and imaginaries of American studies. Ironically, "Black Europe" has continued to be inscribed long after "Black Americans" have become African Americans.

The conflation of African diaspora formations with the histories and geographies of Atlantic slavery disregards the histories of other African diasporas in the Americas, both during the period of the slave trade and after. To begin with, it fails to problematize the identity of the very Iberians-the Spanish and Portuguese-who began the conquest of the Americas. Among them were peoples of African descent who had been resident in Iberia for centuries. On my trip to Spain this summer, an Afro-Spanish scholar and activist insisted that Spanish identity only fully dis-Africanized itself following the country's inclusion in the European project (Toasije 2009). The joke that Africa began at the Pyrenees articulates Spain's and Portugal's mixed historical heritage from the Moors (or, according to some, Muslims, Arabs, or Berbers-the designations are themselves quite revealing) who conquered and ruled large parts of the peninsula between 711 and 1492. In the view of Anouar Majid (2000:77), a Moroccan scholar, Al Andalus could be considered "essentially an African kingdom in Europe." Recent work on the migrations of the Moriscos, Ladinos, and even Cape Verdians to the Americas is pertinent in this regard (Garafalo forthcoming; Molina \& López 2001). 
The findings on the free Afro-Iberian migrations to the Americas serve to qualify, but do not of course displace, the centrality of forced migrations from western Africa to the Americas. But in its universalizing ambitions, the Afro-Atlantic model easily yields to a Eurocentric conception of Africa in which Africa, Hegel's (1956:91) "Africa proper," entails sub-Saharan Africa and African diasporas are exclusively "black," a paradigm that leads to a preoccupation with the formation of black racial identities among African diasporas. This model also ignores the formation of "new" African diasporas out of voluntary migrations since the abolition of slavery and especially since decolonization.

Over the last two decades, more African migrants have been arriving in the United States than during the Atlantic slave trade. As shown in the recent capacious collection by Isidore Okpewho and Nkiru Nzegwu, The New African Diaspora (2009), the mobilities, experiences, identities, and dialogues of these diasporas differ and intersect with those of the historic Afro-Atlantic diasporas in complex and contradictory ways. ${ }^{6}$ The very existence of intercultural and intertextual diaspora spaces in which they find themselves ensures complex negotiations and performances of racial, national, ethnic, and gender identities that are neither already fixed in the diaspora nor imported from Africa. And of course we know the identities of the historic Afro-Atlantic diaporas are not frozen; they have continually been reconstructed and reshaped by changing economic, social, cultural, and political contexts, and through the dialogic and dialectical interplay of material and discursive processes, the shifting structures of power, and the agencies of resistance.

But even for the historic Afro-Atlantic diasporas, some scholars object to the regionalization of the African American model in which the U.S. experience and modes of racialization and identity formation are often generalized to the rest of the Americas, even though Afro-Latin America, which is more than twice as large as Afro-North America, has its own quite distinctive histories. Paul Gilroy's influential Black Atlantic (1993), which ignores both Africa and Afro-Latin America, exemplifies this Anglophone analytical conceit. Let me hasten to add that in recent years many U.S. diaspora scholars have produced excellent comparative studies of Afro-Atlantic diaspora histories and anthropologies. The works by Sheila Walker (2001), George Andrews (2004), and Kevin Yelvington (2006) readily come to mind.

\section{Historical Mappings}

The Afro-Atlantic model is clearly inadequate when applied to the much older and more complicated histories of African interactions with, and diasporas in, Europe and Asia. I am struck by the amount of intellectual energy expended in trying to restrict the histories of African movements to Europe and Asia, and to force the formation of African diasporas in these regions into the Atlantic model by seeing their movements primarily in 
terms of slavery and sub-Saharan Africans. "Africa" and "Africans" of course include "blacks" but are not confined to them, and before the twentieth century some Africans went to Europe and Asia as enslaved people, but not all, perhaps not even the majority, and their identities were not always framed by American-style regimes of racialization. Other social inscriptions and ideologies such as religion sometimes played a more salient role.

Systematic studies of African diasporas in Europe and Asia are a recent phenomenon. Both are inspired by some of the same forces noted earlier. In the case of Europe, additional impetus has been provided by the increased African migrations over the last few decades and by European anxieties, which have manifested themselves both in the development of multiculturalism as public policy and in xenophobic violence. In Europe the definitional challenges are thrown into particularly sharp relief: do we talk of "black" or "African" diasporas, "Black Europe" or "Afro-Europe"? Some of the scholarship on "Black Europe," "Black Britain," "Black France," and so on, is illuminating, but much of it, which seems to borrow uncritically from the Atlantic model, is clearly problematic. These works are often written by African American scholars, specialists in African American studies, or Afro-European scholars who have discovered their epistemic and existential blackness on American campuses and remained in the United States; an example of the latter is Pap Ndiaye (2008), the Afro-French historian, whose celebrated La Condition Noire was inspired by his studies of African American history. ${ }^{7}$

"Who are these Black Europeans?" asks Philomena Essed (2009:xii) in the forward to Hine et al.'s edited collection, Black Europe and the African Diaspora, and she answers: "I am not sure." The editors and authors are less equivocating: for many of them Black Europe includes descendants of sub-Saharan Africans, indeed preferably secondary diasporans transplanted from Afro-America. In some of these texts, continental Africans tend not only to be marginalized as recent immigrants who are as yet unqualified for diasporic status, but also to be segregated by the melanin sands of the Sahara. Put quite simply, Black Europe includes sub-Saharan Africans and excludes North Africans. In this regard, "Black Europe" is an incomplete part of Afro-Europe. Across Europe there are as many people from so-called sub-Saharan Africa as from North Africa, so the size of the African diaspora depends on whether both groups are counted or not. No wonder the estimates range from 8 million to 22 million!

Indeed, such is the malleability of "blackness" that it has meant different things even in Britain and the United States, despite their "special relationship" and shared linguistic heritage. Until recently, in Britain the term black referred to both peoples of African and Asian descent-the formerly colonized peoples of color who were seen as the national "other," inauthentic citizens who could never be truly British, an identity equated with whiteness. This multiracial condition of "blackness," however, crumbled in the face of the destabilizations of multiculturalism, new waves of migration 
from Africa and Asia, and the changing constructions, imbrications, and politics of race, ethnicity, class, and sexuality in postimperial Britain (see Owusu 2000; Rattansi 2000; Alexander 2002; Christian 2002).

If one were to periodize the African presence in Europe within historical memory-to use the African Union's (2004) definition of African diaspora communities that they should have been formed within "historical memory," a rather vague formulation but one that avoids going back to prehistoric times or even the great migrations out of Africa to populate the planet - then four broad periods can be distinguished: what I would call ancient times (before the fifteenth century), which can be further subdivided; slaving Europe (the sixteenth to the mid-nineteenth centuries); colonial Europe (the mid-nineteenth to the mid-twentieth centuries); and postcolonial Europe (since decolonization).

Clearly there have been variations in the periodization, size, and formation of African diasporas in different parts of Europe. For example, in southern Europe one could go back to Roman times, in central and eastern Europe to medieval times (including the era of the Crusades and Ottoman expansion, in which tens of thousands of soldiers from Africa were deployed in Turkish armies), and western Europe to the African conquests of the Iberian Peninsula. Many of the descendants of these diasporas were assimilated into European society, although only those who distinguished themselves, such as the descendants of Abraham Hannibal (including the famous Russian writer Alexander Pushkin), are remembered; others survive in archeological artifacts, iconographic representations, and more recently DNA excavations.

Unlike Afro-America, then, the vast majority of Europe's African diasporas today are increasingly descended from or are members of the "new" diasporas. In the Americas the historic Afro-Atlantic diasporas predominate and will continue to do so for the foreseeable future. This is certainly true of Afro-Latin America, where the extent of postcolonial African migration pales in comparison to the situation in Afro-North America. Thus the composition of Europe's "overlapping" diasporas is quite different from that of the Americas. This affects the patterns of integration and identity formation for the new diasporas, whose class composition also tends to vary because of the social costs of relocation. This is becoming evident in comparative studies, such as John Arthur's (2008) recent study of the Ghanaian diaspora in the United States and Europe.

For example, in France, which hosts the largest African diaspora in Europe, there are at least four groups of diasporas: long-standing communities of African descent, Antillean Blacks, Africans from West and Central Africa, and Africans from North Africa. These communities have complex relations with one another and with the French state and the wider society, in which the schisms and solidarities of race, religion, region of originnot to mention nationality, class, and gender-play significant and shifting roles. Many West Africans, for example, may identify racially with the 
Antilleans, religiously with the North Africans, and subregionally with the Central Africans.

It could be argued that the histories of African diasporas in Asia are perhaps the most complicated of all. This could of course simply reflect my own ignorance as a scholar educated and brought up in Anglophone and Afro-Atlantic traditions. The difficulties of studying these diasporas, I would submit, in part reflect the dominance of the Atlantic model itself and of Eurocentric scholarship. There are widespread Western assumptions that interactions among the world's various regions and peoples were a product of the European-dominated modern era of the last five centuries. It is also often believed that African extracontinental movements were confined to the Americas, as symbolized by the slave ship. The reality, of course, was a lot more complex. As anybody who has seriously studied Indian Ocean histories knows, interactions between Africa and Asia long predated the establishment of European global hegemony in the sixteenth and seventeenth centuries (see Keita 2005). Also, African movements involved both free and forced migrations.

Another problem arises out of Western racialized constructions of Africa and Africans, Asia and Asians, and Arabia and Arabs. As it was stressed to me when I visited the Gulf, Arabs range from white-looking Syrians to brown-skinned Yemenis and dark-skinned Sudanese. The epistemological implications of the fixations on "race," and the colonial constructs of the presumably immutable identities of the peoples of the two continents, is now well known thanks to the works of Edward Said on Orientalism and V. Y. Mudimbe on the invention of Africa, and their numerous followers. It is difficult, but we must develop the historical imagination to understand that the constructions of racial identities in the Americas, or more specifically the U.S., do not have universal applicability or meaning.

Afro-Asian interactions after prehistoric times could be divided into five periods: what I would call ancient interactions between Pharaonic Egypt and western Asia and ancient Ethiopian connections with the Arabian Peninsula, both of which involved conquests and counterconquests; interactions of the classical era under the Greek and Roman empires; interactions of the Islamic era; interactions of the European era from the fifteenth and sixteenth centuries; and contemporary interactions since decolonization. This periodization underscores a simple point: that major global demographic movements and diaspora formations have been tied historically to the establishment and expansion, ruptures and realignments of empires.

The spatial dimensions of these interactions involved the Mediterranean-Red Sea corridor linking northern Africa with western Asia, the Red Sea-Indian Ocean corridor linking northeastern Africa with western and southern Asia, and the Indian Ocean corridor linking eastern Africa with Indian Ocean islands and Asia. Today, of course, other connections are facilitated and reinforced by the ubiquitous modern transport, by communication and information technologies, and by Africa's growing economic 
linkages with Asia. The first corridor raises interesting questions. One of my hosts in Oman insisted that Africa and Arabia are one continent, save for the "crack" of the Red Sea. This echoes Ali Mazrui's (2008) suggestive notion of "Afrabia": that Africa and Arabia constitute a contiguous, indeed overlapping, space. Mazrui identifies four factors arguing for the convergence of Afrabia: cultural, geographic, ideological, and genealogical.

If we take into account the above spatial and temporal dimensions, the patterns of dispersal were extremely varied and complex. Much of the literature focuses on three patterns of sub-Saharan African migrations over the last two thousand years: to western Asia-the region from Arabia to Iran-from the first millennia; to South and East Asia from the second millennia; and to the Indian Ocean islands from the fifteenth century. These migrations took place under the last three periods mentioned above (Islamic, European, and contemporary). The dispersals were characterized by free movements-in which African merchants, proselytizers, entertainers, sailors, and soldiers moved and settled in what we today call Asia-as well as unfree movements under the Arab and European slave trades.

The emerging literature is emphatic on the subject of the dual and indeed multiple modalities of African mobilities in the Indian Ocean worlds before the twentieth century. Many scholars stress that there was never any huge demand for African labor in densely populated Asia or the barren desert lands of the Gulf. Yet in many of these texts, such obligatory declarations seem to have little bearing on the actual analyses, which seem to revert to narratives of slavery and diaspora identities that are familiar in Afro-Atlantic narratives. This is true in many of the contributions in The African Diaspora in the Indian Ocean (Jayasuriya \& Pankhurst 2003), the voluminous African Diaspora in Asia: Explorations of a Less Known Fact (Prasad \& Angenot 2008), the thinner collection Uncovering the History of Africans in Asia (Jayasuriya \& Angenot 2008), and Shihan de Silva Jayasuriya's recent African Identity in Asia: Cultural Effects of Forced Migration (2009). This might be a reflection of the pervasive tentacles of the Afro-Atlantic model, the nature of the sources, the sheer difficulties of reconstructing histories of migration between these regions, or the simple fact that free African dispersals to Asia were not reconstituted into diasporas. Only more research will tell.

Nevertheless, in comparison to the Americas, it is clear that African movements to Asia have a much longer history, the patterns of dispersal were more varied, and the processes of diasporization far more complex. As noted earlier, as a process, diasporization begins with dispersal from a homeland and the development of a diaspora consciousness. The latter entails developing collective memories of the homeland, traditions of return or engagement, and transnational networks. Critical in this process is the way the dispersed are treated in terms of the prevailing socioeconomic conditions and regimes of racialization in the hostlands as well as the nature of 
the interactions they are able to maintain with the homeland directly and indirectly, real and imaginary, substantively or symbolically.

It has been argued that diasporic consciousness among the dispersed Africans in Asia was weaker than in the Atlantic world because of their relatively small size and the slow and long duration of their migrations, which facilitated assimilation into host populations. In other words, their dispersals lacked the temporal and geographic concentration of the Americas. Also, the varieties of names by which Africa and the Africans have been known in Asia undermined the development of collective identities as "Africans" or "black." They were often known by their specific regions of origin in Africa rather than as Africans-Sudan, Habasha, Zandj, Nuba, Baburu, Takruni, Abid, Mawalid, Kaffir, Habshi, Sidi, and so on (Jayasuriya 2006).

No less important are the complexities of color and race in Asian societies in which there are many Asians who are as dark as many sub-Saharan Africans and as light as many North Africans. Color, in this case "blackness," therefore, is not always a reliable indicator of "Africanness." There has also been considerable debate on the role played by the integrative mechanisms and ideologies of Islam in parts of Asia. Claims have been made among writers ranging from John Hunwick and Eve Powell in The African Diaspora in the Mediterranean Lands of Islam (2002), to Ali Mazrui in The Africans: The Triple Heritage (1986), that even for the enslaved, Islam provided better prospects for social assimilation compared to segregated Christianity in the slave societies of the Americas. Furthermore, there was an apparent absence in Islamic cultures of systematic violence, legal segregation, and racial and ethnic discrimination on the Atlantic pattern, and a paucity of leadership to develop and articulate diasporic consciousness and interests.

Whatever the case, the Atlantic model is not terribly helpful in deciphering the full dimensions and complexities of African diasporas in Asia. Asia is of course a huge continent, so it is important to distinguish the various locations of African diasporas on which historical sources exist and a significant body of knowledge is growing. The Indian Ocean islands pose a special definitional problem insofar as they are a part of Africa and their African populations, from a continental perspective, could be considered part of intra-African diasporas. The islands are also home to Asians and Europeans, so that over the last few centuries they have emerged as the quintessential meeting grounds for Africans, Asians, and Europeans. In some sense, they resemble the Caribbean in terms of the dynamics of creolization.

For Asia proper, there are three key zones. First, Africans in the Arabian Peninsula, in which population movements on both sides have gone on for centuries ranging from the various Red Sea Empires, including those of Ethiopia, to the rise of Islam to the Arab slave trade. The African presence in this region is unmistakable, and the African diaspora has had a marked impact on the region's cultures, economies, and polities. Contemporary 
migrations have been fueled by the astronomical growth of the oil economy. In 2005 Saudi Arabia reportedly had the second largest African-born population in the world after France, estimated at 1.5 million.

There is also a long history of African settlements in the Persian Gulf regions of southern Iraq and Iran. The Africans came from multiple geographic and social origins and occupations. In southern Iraq, for example, the African presence, which goes back to antiquity, became concentrated in Basra from the seventh century when an Ethiopian soldier, Abu Bakra, settled in the city. There are several well-known scholars of African descent whose works have survived to this day, such as Abu 'Uthman' Amr Ibn Bahr al-Kinani al-Fuqaimi al-Basri, known to posterity as al-Jahiz (ca. 776-869), author of the book The Glory of Blacks over Whites, translated in the 1980s. Southern Iraq is best known for the Revolt of the Zanj (868-883), which dealt a severe blow to slavery and contributed to a crisis in the Abbasid caliphate. More recently it was reported that since the incredible victory of Barak Obama, black Iraqis, of whom they are an estimated 2 million, have portrayed Obama as a model worth emulating" (Dougherty 2009).

Finally, there is South Asia, principally Pakistan, India, and Sri Lanka. In India, which I visited this summer, there is ample evidence of Africans in the country going back at least to the thirteenth century. They came as merchants, sailors, soldiers, and slaves. Variously called Habshi (for Abyssinia) and Siddi (meanings vary-according to one definition, the term is derived from Sayyid, Arabic for master), they have played various important roles in the political, military, and social life of the country's various empires and kingdoms from the Delhi sultanate to Mughal India.

The African Indian presence was quite marked in several parts of the country from the north (Alapur and Jaunpur), to the northeast (Bengal), to the south (Deccan), to the west coast (Janjira, Goa, and Calicut), to the northwest (Cambay to Gujarat), to the interior (Hyderabad). In fact, African Indians became a powerful political force in their own right in the Deccan in the late fifteenth and early sixteenth centuries and established several sultanates including Bijapur, Golcanda, and Ahmadnagar. Two of the African kingdoms in India-Janjira, established in 1618 by Sidi Ambar Sainak, an emissary of the legendary Habshi military leader Malik Ambar; and Sachin, founded by Sidi Mohammad Abdu l-Karim Khan in 1791survived until the time of India's independence in 1947, when they joined the new state. To quote the titles of two books, the positions of Africans in India ranged From Slavery to Royalty (Chauhan 1995), and African Elites in India (Robbins \& McLeod 2006) have long existed, though unimaginable in the Americas until recently. In fact, when I met Chauhan at the National Museum in New Delhi where he is director of exhibitions and public relations, he greeted me with the colorful statement: "There are many Obamas in India." After a dramatic pause, he explained, "There were many African rulers in India." 


\section{Conclusions}

In global terms, then, there are at least three sets of African diasporas: the trans-Indian Ocean diasporas, trans-Mediterranean diasporas, and transAtlantic diasporas. Each of these diasporas has its own histories, and they share similarities, differences, and parallels that are exceedingly difficult to analyze. Many of our analytical paradigms and preoccupations, at least in the Afro-Atlantic world, tend to be derived from the experiences of the trans-Atlantic diasporas, the most recent, historically, of the African global diasporas.

We need to develop better and more comparative understandings of the histories of Afro-Asia, Afro-Europe, and Afro-America. It cannot be overemphasized that there are subregional differences among these diaspora collectivities; the histories of Afro-Latin America and Afro-North America, for example, have not been mere replicas of each other. Almost as a matter of course, such comparative analyses will help decenter the hegemony of the Atlantic model of diaspora studies and some of its unproductive analytical proclivities.

A key question in the history of African diasporas centers on the nature and dynamics of their engagements, linkages, connections, dialoguespick your analytical metaphor-with Africa. For some diasporas these have been intense and for others they have been weak or even nonexistent. Engagements and dialogues are subject, of course, to the shifting mediations of particular historical moments. The diasporas and Africa have served as signifiers for each other, susceptible to strategic manipulation and subject to the changing constructions of their respective identities, social positionalities, and political economies. The engagements and dialogues have encompassed movements, trafficking, and flows of people, cultural practices, productive resources, organizations and social movements, ideologies and ideas, images and representations, including the very signifier of "Africa" itself.

In general, the new diasporas enjoy stronger linkages with Africa than the older diasporas did. And among the latter there are differences of magnitude among the diasporas in the Americas, Europe, and Asia mediated by resources available to each one, the connections between their respective countries and Africa, and the flows of new African migrations. Each diaspora community has its own commitments and imaginations of Africa. A critical part of building diaspora linkages is knowledge production. As intellectuals, we are often as involved in transcribing diaspora identities as in inscribing them, indeed even in creating them. That is why for a more pluralistic and productive global history of African diasporas, one that is suited to the pan-Africanism and internationalism of the twenty-first century, we need to conceptualize and construct more complex diasporas. Besides, this may also be historically more accurate. 
As I reflect on the task I set myself five years ago, I did not fully appreciate how daunting it would be. It has been much harder, but also infinitely more stimulating, than I could have imagined. The sheer volume of the literature on the subject, the range and intensity of debates, the expanding analytical focus in time, space, and conception-from geography to gender, diaspora discourses and engagements, textual to digital diasporizationhave been amazing, a source of both immense trepidation and inestimable intellectual pleasure. The more I learn, the more questions I have, and the less certain I am of the answers I used to have. I recall my conversation with Tade Aina in 2002. This project will keep you busy for the rest of your academic life, he said, with that endearing and mischievous laugh of his. He was right, and for that I am grateful, for I believe that the enduring questions of the place of Africa in the world, and the world in Africa, of the intersections of African and world histories, will remain, even after some of the current fads of diaspora studies have passed.

\section{References}

African Union. 2004. "African Union Technical Workshop on the Relationship with the Diaspora." June 2-5, Port of Spain, Trinidad and Tobago. www.democracyafrica.org.

Alexander, Claire. 2002. "Beyond Black: Re-thinking the Colour/Culture Divide." Ethnic and Racial Studies 25 (4): 552-71.

Andrews, George. 2004. Afro-Latin America 1800-2000. New York: Oxford University Press.

Arthur, John A. 2008. The African Diaspora in the United States and Europe: The Ghanaian Experience. Burlington, Vt.: Ashgate.

Chauhan, R. R. S. 1995. Africans in India: From Slavery to Royalty. New Delhi: Asian Publication Services.

Christian, Mark, ed. 2002. Black Identity in the Twentieth Century: Expressions of the U.S. and U.K. African Diaspora. London: Habsib.

Davies, Carole Boyce, ed. 2008. The Encyclopedia of the African Diaspora: Origins, Experiences, and Culture. 3 volumes. Santa Barbara, Calif.: ABC-CLIO.

D'alisera, JoAnn. 2004. An Imagined Geography: Sierra Leonean Muslims in America. Philadelphia: University of Pennsylvania Press.

Dougherty, Jill. 2009. "Black Iraqis Make Obama a Model to Follow." CNN, January 19. www.cnn.com.

Falola, Toyin, and Matt D. Childs, eds. 2004. The Yoruba Diaspora in the Atlantic World. Bloomington: Indiana University Press.

Garafalo, Leo. Forthcoming. "The Shape of a Diaspora: The Movement of AfroIberians to Colonial Spanish America." In Africans to Spanish America: New Directions, edited by Ben Vinson and Sherwin Bryant. Urbana: University of Illinois Press.

Gilrdoy, Paul. 1993. The Black Atlantic: Modernity and Double Consciousness. Cambridge: Harvard University Press.

Hegel, G. W. F. 1956. The Philosophy of History. New York: Dover Publications.

Heywood, Linda M., and John Thornton. 2007. Central Africans, Allantic Creoles, and the Foundation of America. New York: Cambridge University Press. 
Hine, Darlene Clark, Trica Danielle Keaton, and Stephen Small, eds. 2009. Black Europe and the African Diaspora. Urbana: University of Illinois Press.

Hunwick, John, and Eve Powell. 2002. The African Diaspora in the Mediterranean Lands of Islam. Princeton, N.J.: Markus Wiener.

Jayasuriya, Shihan de Silva. 2006. "Identifying Africans in Asia: What's in a Name?" African and Asian Studies 5 (3-4): 275-303.

2009. African Identity in Asia: Cultural Effects of Forced Migration. Princeton, N.J.: Markus Wiener.

Jayasuriya, Shihan de Silva, and Richard Pankhurst, eds. 2003. The African Diaspora in the Indian Ocean. Trenton, N.J.: Africa World Press.

Jayasuriya, Shihan de Silva, and Jean-Pierre Angenot, eds. 2008. Uncovering the History of Africans in Asia. Leiden: Brill.

Jules-Rosette, Bennetta. 2000. Black Paris: The African Writers' Landscape. Urbana: University of Illinois Press.

Keita, Meghan. 2005. "Africans and Asians: Historiography and the Long-View of Global Interactions.” Journal of World History 16 (1): 1-30.

Konadu-Agyemang, Kwado, Baffour K. Takyi, and John A. Arthur. 2006. The New African Diaspora in North America: Trends, Community Building, and Adaptation. Lanham, Md.: Rowman \& Littlefield.

Lewis, Gordon. 1999. Bad Faith and Antiblack Racism. Amherst, N.Y.: Humanity Books.

Majid, Anouar. 2000. Unveiling Traditions: Postcolonial Islam in a Polycentric World. Durham, N.C.: Duke University Press.

Manning, Patrick. 2009. The African Diaspora: A History Through Culture. New York: Columbia University Press.

Martone, Eric, ed. 2009. Blacks in European History and Culture. 2 volumes. Westport, Conn.: Greenwood Press.

Mazrui, Ali A. 1986. The Africans: A Triple Heritage. New York: Little Brown. 2008. Euro-Jews and Afro-Arabs: The Great Semitic Divergence in World History. Edited by Seifudein Adem. Lanham, Md.: University Press of America.

Molina, Lucía Dominga, and Mario Luis López. 2001. "Afro-Argentinians 'Forgotten' and 'Disappeared'-Yet Still Present." In African Roots/American Cultures: Africa in the Creation of the Americas, edited by Sheila S. Walker, 332-47. Lanham, Md.: Rowman \& Littlefield.

Mudimbe, V. Y. 1988. The Invention of Africa: Gnosis, Philosophy, and the Order of Knowledge. Bloomington: Indiana University Press.

1994. The Idea of Africa. Bloomington: Indiana University Press.

Ndiaye, Pap. 2008. La Condition noire. Paris: Calmann-Lévy.

Ogbaa, Kalu. 2003. The Nigerian Americans. Santa Barbara, Calif.: Greenwood Press.

Okpewho, Isidore, and Nkiru Nzegwu, eds. 2009. The New African Diaspora. Bloomington: Indiana University Press.

Owusu, Kwesi. 2000. Black British Culture and Society. London: Routledge.

Prasad, Kiran Kamal, and Jean-Pierre Angenot. 2008. The African Diaspora in Asia: Explorations on a Less Known Fact. Bangalore: Jana Jagrati Prakashama.

Prashad, Vijay. 2007. The Darker Nations: A People's History of the Third World. New York: The New Press.

Raphael-Hernandez, Heike. 2003. Blackening Europe: The African American Presence. New York: Routledge. 
Raphael-Hernandez, Heike, and Shannon Steen, eds. 2006. AfroAsian Encounters. New York: New York University Press.

Rattansi, Ali. 2000. "On Being and Not Being Brown/Black-British: Racism, Class, Sexuality and Ethnicity in Post-imperial Britain." Interventions 2 (1): 118-34.

Robbins, Kenneth X., and John McLeod. 2006. African Elites in India: Habshi Amarat. Usmanpura, Ahmedabad: Mapin.

Thomas, Dominic. 2006. Black France: Colonialism, Immigration, and Transnationalism. Bloomington: Indiana University Press.

Toasije, Atumi. 2009. "The Africanity of Spain: Identity and Problematization." Journal of Black Studies 39 (3): 348-55.

Walker, Sheila S., ed. 2001. African Roots/American Cultures: Africa in the Creation of the Americas. Lanham, Md.: Rowman \& Littlefield.

Winders, James A. 2006. Paris Africain: Rhythms of the African Diaspora. New York: Palgrave Macmillan.

Yelvington, Kevin A. 2006. Afro-Atlantic Dialogues: Anthropology in the Diaspora. Santa Fe, N.M.: School of American Research Press.

Zeleza, Paul Tiyambe. 2005. "Rewriting the African Diaspora: Beyond the Black Atlantic." African Affairs 104 (1): 35-68.

2006. "The Changing Meanings of 'African' Culture and Identity." In Horizons: Perspectives on a Global Africa, edited by Elisabeth Abiri and Håkan Thörn, 31-72. Göteborg, Sweden: National Museum of World Cultures and Göteborg University.

2008. "Contemporary African Global Migrations: Patterns, Perils, and Possibilities." Journal of Global Initiatives 3 (1): 33-56

. 2009. Diaspora Dialogues: Engagements between Africa and Its Diasporas."

In The New African Diaspora, edited by Isidore Okpewho and Nkiru Nzegwu, 31-58. Bloomington: Indiana University Press.

Zeleza, Paul Tiyambe, ed. 2007a. The Study of Africa. Volume 1: Disciplinary and Interdisciplinary Encounters. Dakar: Codesria Book Series.

. 2007b. The Study of Africa. Volume 2: Global and Transnational Engagements. Dakar: Codesria Book Series.

\section{Notes}

1. For an extensive survey of the development of African studies in the major social science and humanities disciplines, interdisciplines, and various theoretical formations in different countries and world regions, see Zeleza (2007a, $2007 \mathrm{~b})$. For a broad overview of African diaspora studies that informed my project, see Zeleza (2005).

2. This sentiment clearly informs the collection by Heike Raphael-Hernadez and Shannon Sheen (2006) and the work of Vijay Prashad (2007), who seeks to rekindle and reconstruct the Bandung sprit for the twenty-first century.

3. I explore contemporary African global migrations in detail elsewhere (Zeleza 2008).

4. Examples of such works include those on the Nigerian diaspora (Ogbaa 2003), Ghanaian diaspora (Arthur 2008), and Sierra Leone diaspora (D'alisera 2004).

5. The invention and idea of Africa are interrogated in V. Y. Mudimbe's (1988, 
1994) seminal works. I examine the issue at length in Zeleza (2006).

6. Unfortunately, this book remains trapped in the old sub-Saharan paradigm in which North Africa and North Africans are conspicuously absent. In my essay in the volume (Zeleza 2009), in which I explore the complex and sometimes fraught engagements among the different segments of African diasporas, I explicitly include North Africans. Konadu-Agyemang et al. (2006) do a better job in this regard insofar as North African migration data is incorporated in several of the chapters.

7. Many of these works celebrate the African American presence in Europe (Raphael-Hernandez 2003), the sub-Saharan African presence (Winders 2006), or the encounters between the two groups (Jules-Rosette 2000; Thomas 2006). 


\section{$\checkmark$ A frican \\ $\Rightarrow S$ tudies \\ A ssociation}

\section{The African Studies Association}

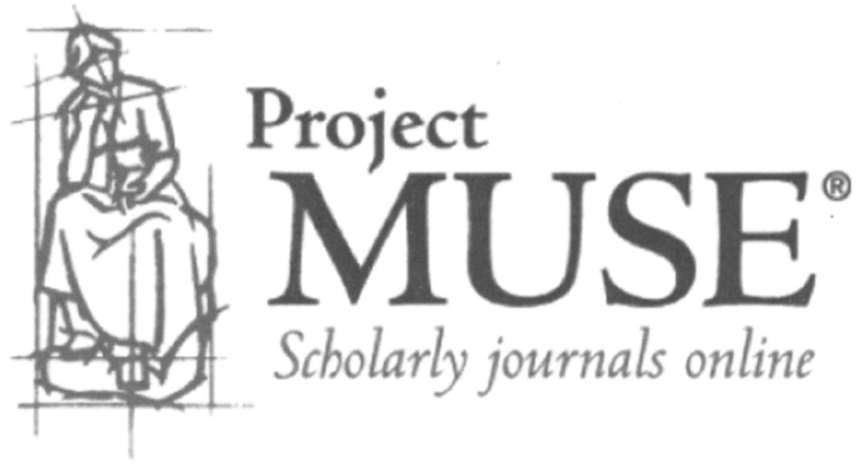

Founded with the input of both librarians and publishers, Project MUSE is a unique collaboration providing affordable, userfriendly, online access to $100 \%$ full text articles from prestigious arts, humanities, and social sciences journals for the most recent three years of their publication. The collection includes the African Studies Review and History in Africa. For more information please visit: HTTP://MUSE.JHU.EDU 